\title{
Entrepreneur Network Behavior as the Gamechanger for Venture Performance : the Mediation Effect of Social Capital and Tacit Knowledge
} Isaac Gumah Akolgo ${ }^{1}$, Cai Li ${ }^{1}$, Peter Yao Lartey ${ }^{1}$, Kankam William Adomako ${ }^{1}$

Department of Business Administration, School of Management, Jiangsu University, 301 Xuefu Road, Zhenjiang 212013, Jiangsu, P.R. China.

*Corresponding author Cai Li (gscaili@ujs.edu.cn)

\section{ABSTRACT}

The individual characteristics continue to set apart who a successful or failed entrepreneurs and business ventures are in the business environment. The study therefore sought to investigate network behavior mechanism as a gamechanger for venture performance; the mediation effect of social capital and tacit knowledge.

Entrepreneurs here were regarded as individuals who created their businesses and therefore respondents other than owners were not included in the study population. In total, 530 entrepreneurs were selected from three cities in Jiangsu Province. Purposive, convenient and simple random sampling techniques were applied in choosing the respondents. 410 completed questionnaires were retrieved.

The results show that entrepreneurs engaging in network building attitude, network maintenance and network orientation determined their network behaviour. Network behaviour then positively and directly influences venture performance. This effect was significant showing that any effort or activities that lead to network behavior wield a corresponding effect on startups business performance. The results indicated that social capital mediated the relationship such that entrepreneur network behavior indirectly influences venture performance. Tacit knowledge acquisition was shown to boosts network behaviour effect on venture performance.

This study departs from the psychological perspective which mainly focus on stable features of the entrepreneur to include the behaviour mechanisms hence makes the study central to better understand the entrepreneurial behavior and performance relationships.

Keywords : Entrepreneur, Network Behaviour, Social Capital, Tacit Knowledge, Venture Performance

\section{INTRODUCTION}

In recent decades, the entrepreneur and Entrepreneurship have been given much attention in social science research. In economies, entrepreneurial activities are linked with high esteem and entrepreneurs are touted for significantly contributing to national development. It is obvious that entrepreneurs create jobs, promote healthy competition, champion economic growth and promote an inclusive society (Wiklund et al., 2019). There has been growing interest among scholars in exploring the entrepreneur characteristics in relation to venture creation and performance. However, many previous entrepreneurship scholars either paid attention to understand the aspect of the entrepreneur characteristics which are more stable or the influence of the environment on startups 
performance. Not many researchers have actually explore the influence of both entrepreneurial behaviour and the entrepreneur's surrounding environment context in the entrepreneurial process (Hoogendoorn et al., 2019). This study sought to understand how entrepreneurial behaviour (network) viewed as individual differences and the environment relate to venture performance. By focusing on entrepreneurial networking behavior, the study hopes to enlighten to some extent the understanding of business creation, growth and performance.

Entrepreneurs all over the world need to constantly engage in the organisation of their daily business routines in order to keep their businesses running. How each and every entrepreneur successfully organises his/her entrepreneurial activities in this day of competitive market environment are influenced by many factors. Their ability to get things done successfully or fail is partly linked to the individual entrepreneur distinguishing characteristics (Geenen et al., 2016). Also, the entrepreneurial development process encompasses activities that happens within situations of uncertainty. Entrepreneurs do not have all the requisite information to enable them access the needed opportunities as well as resources. Therefore, entrepreneurs need to overcome this information gap and what matters in the quest to bridge the information gap is access to social networks. When entrepreneurs overcome information asymmetry, they stand a greater chance of succeeding in their entrepreneurial activities.

Although, factors such as government policies, market conditions, values, macro and micro economic indicators may equally contribute to the successful organisation of entrepreneurial activities and superior performance, this paper is of the view that entrepreneurs individual behaviour (network behavior) has been a differentiating factor as far as entrepreneurs success is concern given that all other factors are same for all the entrepreneurs.

Entrepreneurs and businesses are faced with dynamic and changing business environment coupled with scares resources which require entrepreneurs to exhibit some kind of behaviors to enable them perpetuate and grow their businesses. Some researchers, such as Gartner (1988), argues that the entrepreneurial process is of core interest and researchers should be more interested in investigating the individuals actions in the entrepreneurial process rather than the individuals themselves. In laying emphasis on the behavioural approach, Gartner (1988) concluded that the behavioural approach focuses on the establishment of an organisation (business unit) as a circumstantial event which is a product of myriad effects. The entrepreneur behaviour is viewed as a phenomenon solely related to the individual, contrary to a firm behavior which can be observed as discrete units of actions (Kyndt and Baert, 2015). It is behaviour associated with entrepreneurship explored as a process of emergence, the result being the creation of a new self-organized startup (Kloepfer and Castrogiovanni, 2018). Thus, entrepreneurial behaviour is the behaviour of individuals engaged in a process of establishing new startups, gaining superior performance and achieving entrepreneurial success, where the process includes observable components of actions by others. The process of establishing new business startups include undertaking of many different actions such as identifying an opportunity, mobilizing the needed resources, creating the technical know-how and determining a legal form, among others (Lanivich and Practice, 2015).

Previous studies focus on entrepreneur's individual characteristics with regards to age, gender, and the educational qualification reveal that these factors may affect business performance (Wei and Ling, 2015). 
Scholars such as Eddleston et al. (2016) highlighted that female entrepreneurs were likely to become necessity entrepreneurs than exploring entrepreneurial opportunity to become entrepreneurs. Again, in the Chinese institutional context, some researchers reveal that entrepreneurs financial literacy tends to influence the level of entrepreneurs' success and the high possibility of establishing businesses (Njaramba et al., 2015).

The researchers still argue here that though these evidences contribute to explaining entrepreneur performance, questions such as why some individuals would succeed in creating businesses whilst others failed given the same age group, or the same sex, or similar family backgrounds or financial literacy are not properly addressed by these studies and therefore, there is the need to consider entrepreneur's behaviour mechanism. This gap led to some scholars calling for the need to shift research interest into entrepreneur's behaviour (Sandberg and Hofer,1989; Keeley and Roure,1990). Thus, this study believes that entrepreneur network behavior will help to bridge the gap and better explain the differences in the creation, success and performance of venture startup businesses.

\section{THEORETICAL FOUNDATION AND LITERATURE REVIEW}

The paper is grounded on theories that help the researchers to better understand and well explore the entrepreneur behavior in relation to startups performance. Even though there are many theories that are related to entrepreneur behaviour, this study particularly focused on two critical theories that will enhance the understanding and the findings of the study.

\subsection{Theories and Conceptual framework}

The resource-based theory

Resource-based theory originated from strategic management in the early 70's, however, its relevance became the corner stone and main strategy shaping organisational strategies in different ways. The process of performing a resource base view as prescribed in the theory includes identifying the strength and weaknesses from within the firm using indicators that the firm is having an absolute control (Taskov et al., 2011). In the business setting, a firm has little or no control over threats and opportunities. However, the resource-based perspective holds the view that the firm is capable of influencing some vital success factors known as the strength of the firm. In the same way, the firm is unable to achieve success due to certain circumstances, factors or shortfalls arising within the organisation which can be controlled and this represents the weaknesses. In the concept of entrepreneurship, strategists observed that a firm's strength are the underlying factors in assessing the level at which the firm's survival depends on the internal capabilities even in a hostile business environment. In accordance with the resource based theory, a firm's immediate microenvironment may interfere in the smooth operation of the firm and posed as a threat thereby requires the application of internal resources to either neutralised the threats or convert them into an opportunity (De Bruin et al., 2007).

The entrepreneurial success depends on the ability to identify opportunities originating from the surrounding environment by relying on the firm's strength than on what it has little or no control over. The Resource base theory defines the competitive advantage of an entrepreneurial venture if only the resources are rear, valuable, without substitute and capable enough to sustain the competitive advantage. 
Javalgi et al. (2014), observed that the resource base of the entrepreneur must always be non-imitated.

The resource-based theory prescribes that the internal resource base of the firm as well as the business level strategy are crucially linked with the level at which a firm can beat competition. According to Javalgi et al. (2014), the resource base theory also helps firms to identify and develop distinguishing resources within the firm which have value, are rare, cannot easily be imitated and substituted thereby gaining competitive advantage over rivals. The theory advances the point that as competitors find it impossible to create or reproduce such unique resources and for that matter luck competitive edge and would need to examine the resource base view to arrive at resources which generate that competitive advantage (Baumol, 2007).

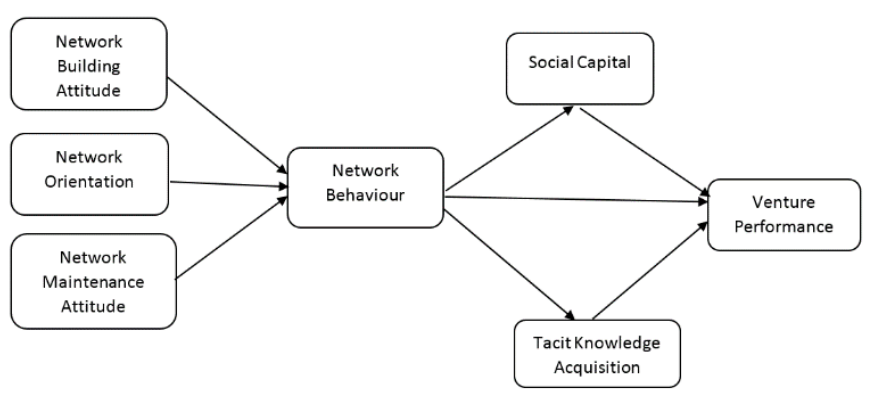

Figure 2.1 Conceptual framework

\subsection{Literature Review and hypotheses formulation}

\subsubsection{Entrepreneur network behaviour and venture performance.}

Entrepreneurs networking behavior in this study encompasses network orientation, network building attitude and network maintenance attitude. How entrepreneurs exhibit their abilities in behaving differently regards to network will determine how well these entrepreneurs perform or fail in their business.
The readiness of entrepreneurs to go the extra mile in their relational efforts to enlarge social ties denotes the entrepreneurs network building attitude. Entrepreneurs can actively monitor their surroundings and undertaking affective initiatives to build their networks. Entrepreneurs who are capable of building social ties often vigorously pursue efforts that will lead to discovery of new partners. In their study, Maurer and Ebers (2006) revealed that there is high possibility for successful entrepreneurs to maintain their existing relationships whilst focusing on creating considerable new outside social ties as well.

In organizing their entrepreneurial activities, entrepreneurs may rely on social networks for their daily socialization needs thereby engaging in network orientation. Evidence from scholarly researches have highlighted that individuals who are highly embedded in network orientation usually take advantage of relational ties to access resources or information from the outside environment (Su et al., 2009).

Not only do entrepreneurs rely on social networks and build such networks but maintain the networks created. The behavior of entrepreneurs to maintain their social networks is critical in facilitating the benefits derived from such networks. In their perspective, Casciaro et al. (2016) opine that in building social relations, people are happy when the other individuals recognize and appreciate their values and personalities which make such people feel as part of them. Entrepreneurs who develop network maintenance behavior are kind and liberal in the network relationship. Such individual entrepreneurs always try to put themselves in their friends' situations and would be in a position to listen and offer them assistance. 
Entrepreneurs in their quest to create business ventures as well as gain superior performance, do face the difficulty in identifying opportunities and mobilising the needed resources to utilise the chances. Social networks serve as a conduit for the entrepreneurs to overcome such challenges and therefore manipulate the entrepreneurial steps. Entrepreneur networks facilitate information flows as well as direct the connections from which financial capital proceeds. Social networks therefore serve as a mechanism through which ideas, knowledge, and capital which are requisite for entrepreneurs to mobilise for the creation of new activities and development are assembled. For instance, Maurer and Ebers (2006) reveal that owners of firms were originally alike in their network embeddedness. Their study highlights that not all these ventures survived that the owners of the startups that achieved more success deliberately engaged in creating and maintaining their social relationships which helped these new firms to link with many different professionals. On the other side, the owners of the firms proved to be less successful encountered social ties locks in their surrounding environment, which hampered their capability to obtain essential messages that is of the market and industry.

The success of an entrepreneurial venture largely depends on the available of useful information being distributed under certain unique circumstances such as interaction with other persons (Dufays and Huybrechts, 2014). From this perspective Memon (2016), noted that when relevant information is being circulated through social circles it turn to narrow the knowledge gap existing between individuals as well as reduces some kind of risk the venture might face. Quite a substantial empirical research has shown that quality and robust network contribute and encourages opportunity creation and identification among entrepreneurs. Hom and Xiao (2011), opined that entrepreneurial network also facilitates discovery of related activities such as the supply chain.

Although, network relationships do not emerge naturally and needs to be developed, maintained and configured. Myriad studies have increasingly focused on network characteristics as exogenous variables as deliberations centered on how diverse network formations relate with entrepreneurial success (Semrau and Sigmund, 2012) whilst only a hand full of researchers have assessed in the first place how entrepreneurs practically build their networks (Maurer and Ebers, 2006).

Entrepreneurs embedded in fewer distinctive networks garner social capital (Nahapiet and Ghoshal, 1998) which helps them to uniquely comprehend what is required and the perception of their outside environment. This formed social capital position people within their social connections to decipher the information they receive and consequently improves the discovery of entrepreneurial opportunities (De Carolis, 2009). Previous studies allude to the fact that having a link to a political party affiliation serves as a conduit for people who intend to be entrepreneurs to tap opportunities as the case during the market transitions in China and Eastern Europe where individuals who had previously served in government and their folks were able to capitalized on their social ties with the state into successful entrepreneurial efforts (Ibarra et al., 2005). From the above review, the researchers sought to formulate the hypotheses below.

H1: Entrepreneur network behaviour directly and significantly influences venture performance.

H1a: Network building attitude positively associate with network behaviour

H1b: Network orientation positively affect network behaviour 
H1c: Network maintenance positively affect network behaviour

\subsubsection{Social Capital, network behaviour and venture performance relationships}

Entrepreneurial capital has been hypothesized into three major categories such as; structural, relational, resources and social capital requirement. According to Grebel (2005), the structural embeddedness represents the entire network of relations. It also includes the size of the network, density and diversity of structural dimensions in the network. According to various researchers studying social capital, relational embeddedness performs a critical function in the effectiveness of the network and the performance of the business venture.

Relational factors also incorporates personal attributes of the individual and how that affects the economic actions of the enterprise (Morrison, 2006). The availability and quality of social capital depends on the nature of ties, bond exiting among individuals. Other researchers believe that every form of capital whether financial, economic, capital resources, has a strong relation with the quality of social capital. Based on these claims Baumol (2007), opined that stronger network relationships possess substantial positive effect on the success of entrepreneurial venture than when there is weak relationships. More so, the social capital depends on social relationships that are based on trust. Memon (2016), noted that unconditional trust in a social network is more rewarding than those principally based on business relations strictly. Social capital enables the entrepreneur to gain access to market information, industry dynamics and reliable supply chain.

Researchers are increasingly examining how social capital relates with resource distribution and the dimensions that affect the entrepreneur's network performance. Considering the benefits of social networks and the impact on social capital, Yeung (2002), opined that multiple or diverse entrepreneur networks that is having members from different backgrounds are having a large impact on the success and performance than when they belong to a single network. Social capital includes transfer of knowledge, improved organisational learning, team work and enhanced capacity building. Social capital may have a direct or indirect relation with entrepreneur's behaviour but the main merits of these element of entrepreneur performance are unlimited just that most of the components and variables have not been tested in some contexts. Empirical researchers examining this relationship are encouraged to take note of the dynamic nature of each environment and industry, the entrepreneur's intention to socialize and the availability of network structures encouraging this relationships(Memon, 2016).

Ameh and Udu (2016) reveal that quality social capital exerts great impact on firms innovativeness and fair market competition among small scale firms. Morrison (2006), observed that, social capital of a person dependent on their relationship with others and that also based on their willingness to contribute to each other's' success in the network. This means that, social capital may not exit if an individual fails to contribute meaningfully and fails to get similar gestures from others. However, there is sufficient evidence in literature supporting the idea that social capital is highly essential in maintaining a durable economic stability. In a related sense, Wong et al. (2005), opined that social capital constitutes a key dimension of entrepreneurship study globally especially its aspect that concerns resource mobilization. For the purposes of resource identification, creation and utilisation, social capital is the fundamental concepts that precedes the pursuit of these collection of theories. Braunerhjelm (2011), noted that over years entrepreneurs exhibit the same 
characteristics by relying deeply on their relational contacts to make good use of the opportunities existing within their market and environment. This also involves distributing, transporting and allocating resources. From the literature reviewed above, the following hypothesis is formulated.

H2: Network behaviour indirectly influences venture performance through social capital.

\subsubsection{Tacit knowledge acquisition, network behaviour and venture performance.}

Knowledge is a critical component for firms and entrepreneurs' success and performance. However, tacit knowledge (the non-coded and embedded individual knowledge) is not always available to all entrepreneurs except those who exhibit some level of network behaviour by building, maintaining and configure their social ties within and outside the entrepreneurial setting. Many researchers are associated with the concept of tacit knowledge however it is widely acknowledged that Polanyi (1966) work on tacit knowledge remains enormous and by far is considered as the founding father of tacit knowledge concept. Entrepreneurs are more interested in tacit knowledge as result of the experience needed to navigate the business sector. Tacit knowledge is often expensive, scares and very limited because it is gained and acquired through experience(Su et al., 2017). Tacit knowledge adds a lot to entrepreneur's success starting from organising resources, sourcing of finance, arranging human, social and economic capital required to start off a business. Javalgi et al. (2014), Hafeez and Abdelmeguid (2003), state that tacit knowledge is important for business innovation, striking negotiations between parties and identifying relevant opportunities.
Certainly, vital for businesses and entrepreneurs to attain competitive edge in this global competitive and turbulent environment is the possession of knowledge (Zheng et al., 2016). To attain and keep competitive edge as well as sustainable growth, startups must continually acquire knowledge that is in existence, acquire new knowledge, and follow applied wisdom (Nonaka et al., 2014). In the development of firms and in the entrepreneurial process, limitation of resources at times adversely affects firms' and entrepreneurs' abilities to undertake innovative strategies to gain competitive edge (Kogan et al., 2017, Xie et al., 2018). As a result of such resource limitations, entrepreneurs and firms weigh a balance between tacit and explicit knowledge since it may be difficult to concurrently concentrate on both of them to achieve the organisation's innovative agenda (Loebbecke et al., 2016). Therefore, the need for entrepreneurs to pay attention to tacit knowledge which they can acquire through their social ties is non-negotiable for gaining for innovativeness, competitive advantage and more importantly higher performance.

Tacit knowledge is profoundly embedded in the minds of individuals having the technical knowhow. This is often gained based on extended period of time and very hard to share and communicated (Ryan et al., 2012). However, management authorities believe that this can be transferred through shared values, organisational culture and interpersonal interactions through networking. In most cases the organisation is responsible for creating the atmosphere to support transfer of tacit knowledge. In laying emphasis on tacit knowledge, Nonaka et al. (2014) affirm that when a firm engages in the appropriate maintenance of tacit knowledge may greatly contribute influentially in innovation performance which consequently enhances the firm's competitive edge. The tacit knowledge serves as a valuable resource for 
entrepreneurs to positively affect their competitive edge leading to superior performance.

H3: Entrepreneur networking behaviour indirectly influences venture performance through tacit knowledge acquisition.

\section{MATERIALS AND METHODS}

The study employed questionnaires through survey for the collection of data from respondents. The data was collected from participants based on network behaviour mechanisms, social capital, tacit knowledge acquisition and venture performance. Each of these constructs were measured on a five Likert scale. Entrepreneur network behavior was measured as a second order construct. Network building attitude, network orientation and network maintenance measured network behavior. The researchers adopted and modified Shu et al. (2017) measurement items in measuring the three constructs. Examples of questions used to solicit data on entrepreneur network behaviour constructs are "I rely on friends most times to identify problems and challenges"; "Having social connections is key in the business environment". Social capital was measured based on previous scholars' measurement items. Questions such as "Entrepreneurial opportunity to start up the business came from families and friends"; "Having social relations with industry players helps me in easy resources accessibility". Tacit knowledge acquisition was measured based on previous researchers measuring items.

Venture performance which is the endogenous variable was measured based on the entrepreneur's perceptions on multiple options. Although, some scholars measure performance on the basis of financial indicators such as liquidity, return on assets and growth rate, the authors focus on the nonfinancial aspect of performance since these small enterprises do not keep proper financial records. The researchers adapted Piercy et al. (1998) measurement items in measuring performance on a five-Likert scale basis.

Tacit knowledge was measured based on previous studies measurement items. The researchers particularly adopted and modified tacit knowledge measurement items from the work of scholars such as Seidler-de Alwis and Hartmann (2008) dimensions of tacit knowledge.

There are many research findings showing that entrepreneur's gender and educational background are capable of affecting business performance (Wei and Ling, 2015). As a result, the researchers included respondents' gender and education as control variables. The control variables were measured in binary form $(1,0)$. For gender, if a respondent is male then he chooses one (1) and zero (0) for otherwise. Respondents were to choose one (1) for having formal education and zero (0) for otherwise.

A purposive sampling was first applied to identify business ventures that have effectively operated for least more than a year. The researchers then applied simple random sampling procedure in selecting 530 respondents. The 530 participants were handed with questionnaires to solicit data. At the ended of the survey process, 410 completed questionnaires were retrieved from the respondents representing 77.4 percent. The 410 completed questionnaires were used as the final sample size for the analysis. The retrieved questionnaires were coded into SPSS. The authors employed SEM AMOS for the analysis since the study sought to establish causal relationships by testing hypotheses among the constructs. SEM was used due to the fact that the covariances and variances of the endogenous variables are being built as a function of the exogenous variables. This is expressed as shown below.

$$
\mathrm{Y}=\Lambda_{\mathrm{y}}[\Gamma \xi+\zeta]+\mu
$$


From equation 5.1 some assumptions were made so as to determine the model. Assumption one was $\operatorname{Cov}(\mu, \zeta)=0$ and $\operatorname{Cov}(\xi, \zeta)=0$. Assumption two was that $\xi$ and $\zeta$ vectors do not depend on other variables signifying that such vectors have effect on the variables' variances or covariances.

\section{RESULTS}

\subsection{Reliability and Validity of the measurement model}

Reliability and validity are key in the measurement model of constructs. Therefore, the researchers conducted these tests with the purpose of proving or otherwise that the collected data satisfactorily measure the study variables. Establishing how reliable and valid the data truly measure the variables are vital especially with scales of psychological in nature employed in measuring behavior related items (Thompson, 2003). With reference to Hair et al. (2013), it is always crucial to ensure that items design to measure the constructs precisely achieve the intended purpose. The study attained unidimensionality for the constructs considered in the study as the factor loadings of all the constructs exceeded 0.70 recommended values for established items. The author, therefore, conducted both validity and reliability tests. In terms of validity, the following were tested; convergent, discriminant and construct whilst reliability test specifically included internal and composite.
The study achieved internal reliability based on the Cronbach's Alpha values. All the Cronbach's Alpha values were higher than the recommended values of 0.70 . With the composite reliability, the author relied on scholars such as (Hair et al., 2013) emphasis where the acceptable value of critical ratio (CR) should be greater than 0.6 . The study results realized $\mathrm{CR}$ values greater than 0.6 indicating that composite reliability was confirmed. The average variance extracted (AVE) values were higher than the 0.50 accepted value. Table 4.1 shows the reliability results.

Convergent validity is usually computed based on the AVE. It is achieved when the AVE is greater than 0.5. The results showed that all the constructs had AVE values greater than 0.5 hence the study confirmed convergent validity. Table 4.2 represents convergent validity results. In testing the construct validity of the measurement model, fitness indexes are usually compared against their recommended values. The results showed that fitness indexes had values within the accepted range hence, construct validity was attained. The results showed that there were no redundant items in the model since all modification indices (MI) were below 15 . Furthermore, the values of the square root of AVEs were higher than the values of the constructs' correlations indicating that discriminant validity was confirmed. Table 4.3 presents the discriminant validity values.

Table 4. 1 Measurement Models and Reliability of Constructs

\begin{tabular}{|c|c|c|c|c|c|}
\hline Construct & Item & Factor loadings & $\begin{array}{c}\text { Cronbach } \\
\text { Alpha }\end{array}$ & AVE & CR \\
\hline \multirow{5}{*}{$\begin{array}{c}\text { Network Building } \\
\text { Attitude (NBA) }\end{array}$} & NBA1 & .903 & \multirow{5}{*}{0.830} & \multirow{5}{*}{0.657} & \multirow{5}{*}{0.820} \\
\hline & NBA2 & .900 & & & \\
\hline & NBA3 & .852 & & & \\
\hline & NBA4 & .893 & & & \\
\hline & NBA5 & .823 & & & \\
\hline
\end{tabular}




\begin{tabular}{|c|c|c|c|c|c|}
\hline & NBA6 & .702 & & & \\
\hline \multirow{5}{*}{$\begin{array}{c}\text { Venture } \\
\text { performance (VEP) }\end{array}$} & VEP1 & .773 & \multirow{5}{*}{0.871} & \multirow{5}{*}{0.794} & \multirow{5}{*}{0.931} \\
\hline & VEP2 & .721 & & & \\
\hline & VEP3 & .701 & & & \\
\hline & VEP4 & .737 & & & \\
\hline & VEP5 & .801 & & & \\
\hline \multirow{5}{*}{$\begin{array}{l}\text { Social Capital } \\
\text { (SOC) }\end{array}$} & SOC1 & .771 & \multirow{5}{*}{0.914} & \multirow{5}{*}{0.780} & \multirow{5}{*}{0.800} \\
\hline & SOC2 & .723 & & & \\
\hline & SOC3 & .741 & & & \\
\hline & SOC4 & .746 & & & \\
\hline & SOC5 & .722 & & & \\
\hline \multirow{4}{*}{$\begin{array}{l}\text { Tacit Knowledge } \\
\text { Acquisition (TAK) }\end{array}$} & TAK1 & .829 & \multirow{4}{*}{0.880} & \multirow{4}{*}{0.663} & \multirow{4}{*}{0.892} \\
\hline & TAK2 & .829 & & & \\
\hline & TAK3 & .888 & & & \\
\hline & TAK4 & .889 & & & \\
\hline \multirow{4}{*}{$\begin{array}{c}\text { Network } \\
\text { Maintenance } \\
\text { Attitude (NEM) }\end{array}$} & NEM1 & .808 & \multirow{4}{*}{0.809} & \multirow{4}{*}{0.702} & \multirow{4}{*}{0.901} \\
\hline & NEM2 & .860 & & & \\
\hline & NEM3 & .892 & & & \\
\hline & NEM4 & .895 & & & \\
\hline \multirow{3}{*}{$\begin{array}{c}\text { Network } \\
\text { Orientation (NEO) }\end{array}$} & NEO1 & .717 & \multirow{3}{*}{0.802} & \multirow{3}{*}{0.583} & \multirow{3}{*}{0.850} \\
\hline & NEO2 & .804 & & & \\
\hline & NEO3 & .771 & & & \\
\hline
\end{tabular}

Source: Authors survey results

Table 4.2 Convergent Validity Results

\begin{tabular}{|c|c|c|c|}
\hline Constructs & CR & AVE & MSV \\
\hline SocialC & 0.800 & 0.780 & 0.166 \\
\hline NetworkBA & 0.820 & 0.657 & 0.207 \\
\hline VentureP & 0.931 & 0.794 & 0.108 \\
\hline
\end{tabular}




\begin{tabular}{|c|c|c|c|}
\hline TacitK & 0.892 & 0.663 & 0.036 \\
\hline NetworkM & 0.901 & 0.702 & 0.102 \\
\hline NetworkO & 0.850 & 0.583 & 0.045 \\
\hline
\end{tabular}

Source: Authors results

Table 4.3 Discriminant Validity Test

\begin{tabular}{|c|c|c|c|c|c|c|}
\hline $\operatorname{MaxR}(\mathrm{H})$ & SocialC & NetworkBA & VentureP & NetworkM & NetworkO & TacitK \\
\hline 0.859 & $\mathbf{0 . 7 4 0}$ & & & & & \\
\hline 0.948 & 0.153 & $\mathbf{0 . 8 4 8}$ & & & & \\
\hline 0.866 & 0.373 & 0.160 & $\mathbf{0 . 7 4 6}$ & & & \\
\hline 0.916 & 0.093 & 0.981 & 0.057 & $\mathbf{0 . 8 8 2}$ & & \\
\hline 0.830 & 0.361 & 0.062 & 0.981 & 0.025 & $\mathbf{0 . 7 9 2}$ & \\
\hline 0.892 & 0.147 & 0.992 & 0.141 & 0.925 & 0.059 & 0.848 \\
\hline
\end{tabular}

Source: Authors compilation

\subsection{Factor and Path Analyses}

Figure 4.1 below represents the confirmatory factor analysis otherwise known as the measurement model which reveals that all the constructs positively correlated.

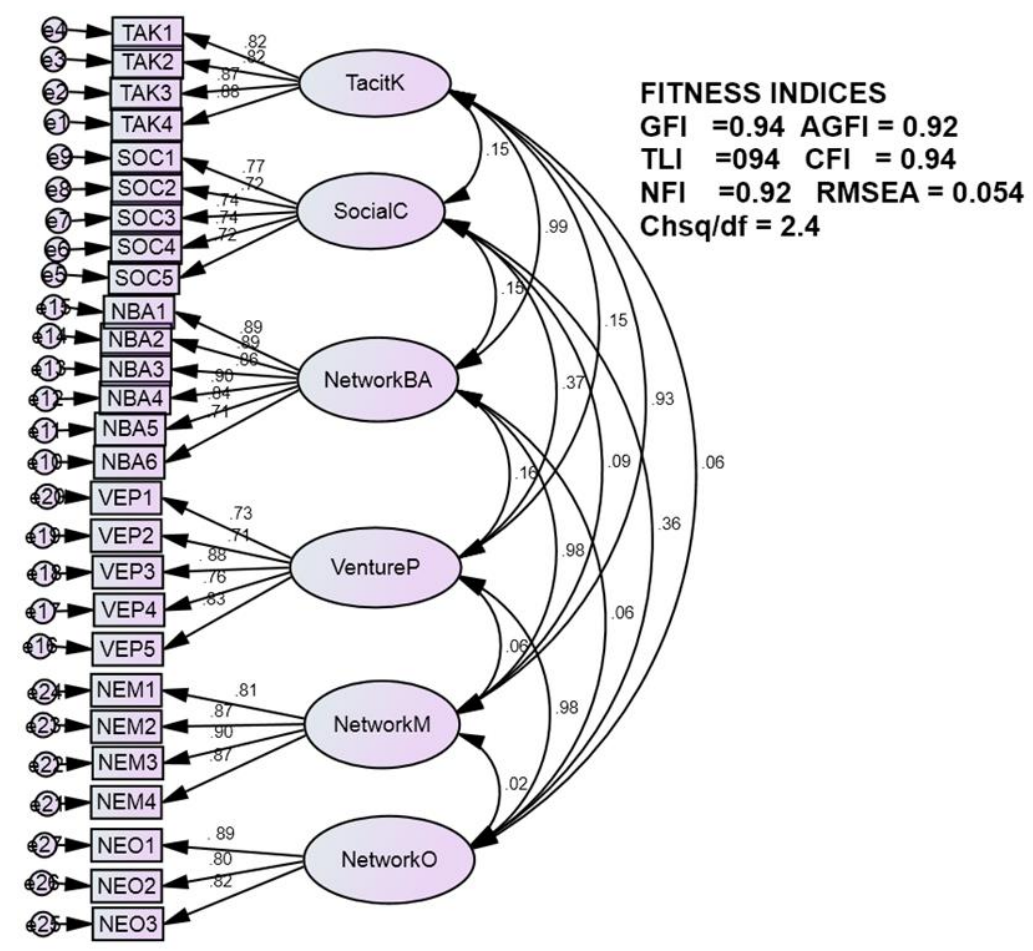

Figure 4.1 Confirmatory factor analysis model 
Figure 4.2 below represents the path analysis of the structural model showing how the independent variables regressed on the dependent constructs. The path diagram sought to establish the existing link between entrepreneur network behaviour and venture performance. The path diagram shows how the independent variable and the endogenous variables regress on venture performance (dependent variable). Tacit knowledge and social capital are mediating the relationships between entrepreneur network behaviour and venture performance.

The structural path determination encompasses path coefficients to determine the structural model relationships and their significance level by establishing the impact of the independent variables on the dependent variable. The path diagram shows the standardized values.

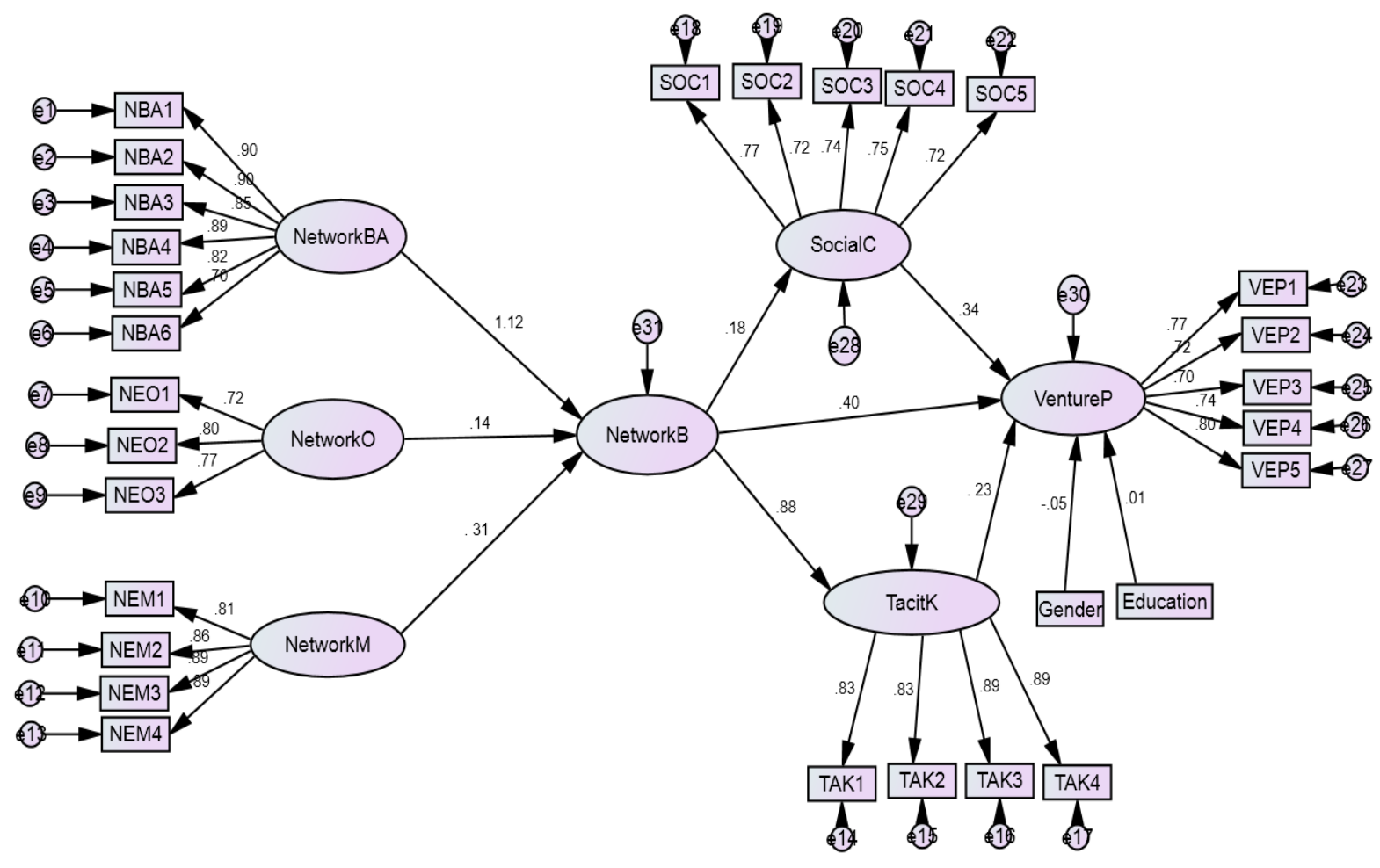

Figure 4.2 Path analysis

Table 4.4 indicates the direct path relationships among the variables under consideration. The result shows that gender and education not significant and therefore has no effect on venture performance. It is evident from the results that network building attitude, network maintenance attitude and network orientation are statistically significant and therefore determine entrepreneur network behaviour. As indicated in table 4.4, network building attitude and network orientation influence network behaviour by coefficient values of 0.808 and 0.155 $(\mathrm{p}<0.001)$. Network maintenance attitude positively affect network behaviour by a coefficient value of 0.06 significant at $\mathrm{p}$ value of 0.001 . Therefore, hypotheses H1a, H1b H1c were confirmed.

Hypothesis $\mathrm{H} 1$ sought to establish that network behavior positively linked with venture performance. As revealed in table 4.4, after treating gender and education as control variables, network behaviour positively impacted on venture $(\beta=0.330, \mathrm{p}<0.05)$. Hence, hypothesis $\mathrm{H} 1$ was validated. 
The results revealed that network behavior directly influences social capital and tacit knowledge $(\beta=0.145, \mathrm{p}$ value $=0.000 ; \beta=0.90$, $\mathrm{p}$ value $=0.000$ ). The path association between social capital and venture performance was positive and significant $(\beta=0.356, \mathrm{p}$ value $=0.000)$. Also, tacit knowledge acquisition had a positive and significant effect on venture performance $(\beta=0.169$, p value $=0.024)$. The establishment of significant relations among these variables provided the researchers with the opportunity to further assess the mediation role of both tacit knowledge and social capital on the relationships between network behaviour and venture performance.

To test for the mediation effect of tacit knowledge and social capital, the researchers relied on the view of Preacher and Hayes (2008) and performed a bootstrap of a resample of 5000. The result shows that the indirect effect ${ }^{1}$ of network behaviour on venture performance through social capital was 0.14 as indicated on table 4.5. From table 4.6, the result reveals ULCI $=0.042$ and LLCI $=0.201$. Since the null hypothesis Ho suggest that the indirect effect is equal to zero, therefore, as the values of both ULCI and LLCI are outside zero, implies that the alternate hypothesis $\left(\mathrm{H}_{1 \neq 0}\right)$ is significant. This means hypotheses $\mathrm{H} 2$ which postulate the indirect relationships between network behaviour on venture performance through social capital was confirmed. The results further reveal that the indirect effect ${ }^{2}$ of network behaviour on venture performance through tacit knowledge acquisition was 0.129 . It was significant since both the ULCI and LLCI $(0.201,0.042)$ are outside zero therefore, hypothesis $\mathrm{H} 3$ was confirmed.

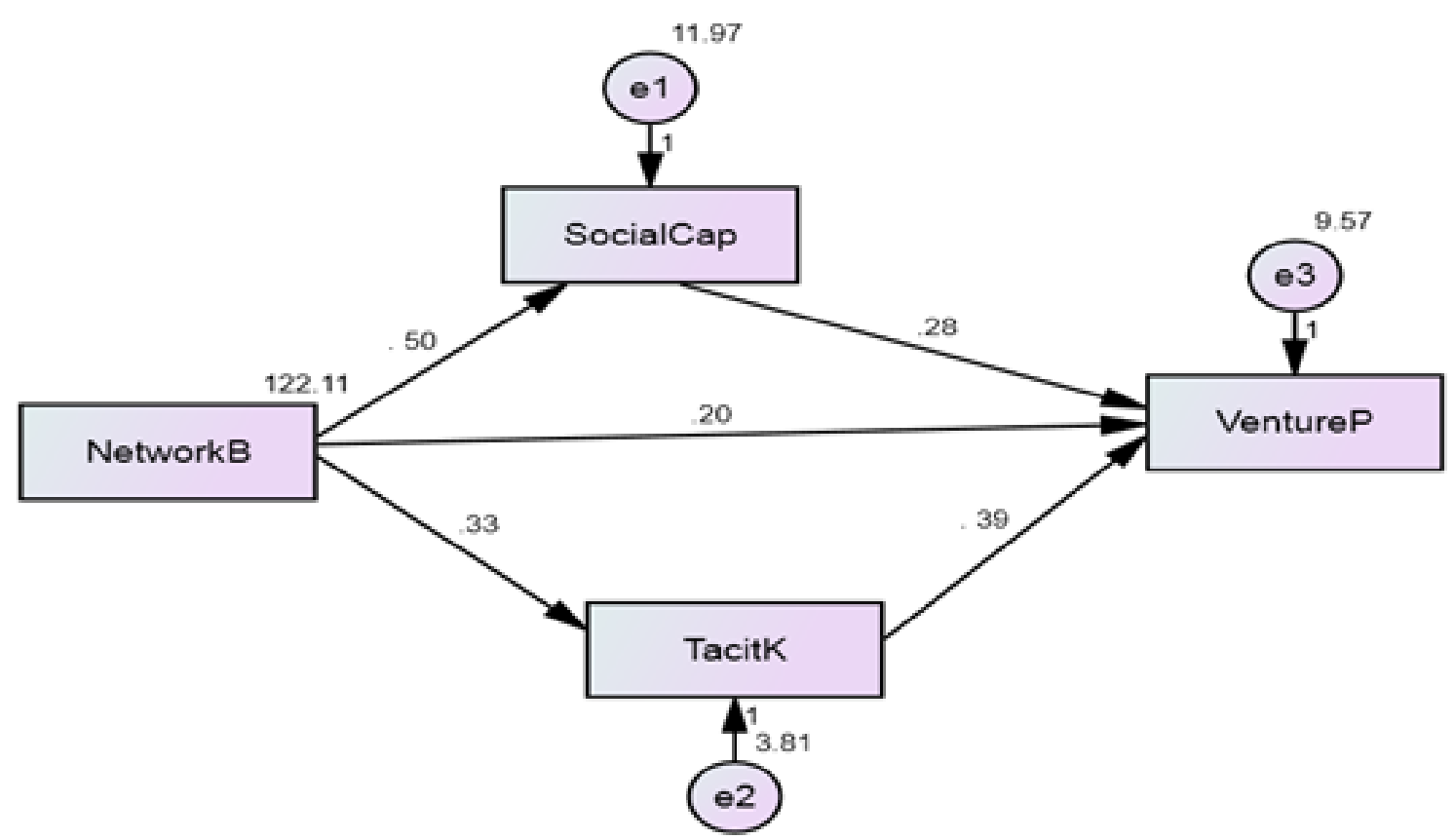

Figure 4.3 Mediation model

\footnotetext{
${ }^{1}$ Indirect effect $=0.50 * 0.280=0.140$

${ }^{2}$ Indirect effect $=0.331 * 0.391=0.129$
} 
4.4 Regression results

\begin{tabular}{|ll|llll|}
\hline & Path directions & Estimate & Standard.E. & C.R. & P \\
\hline NetworkB $<---$ & NetworkBA & .808 & .034 & 23.650 & ${ }^{* * *}$ \\
NetworkB $<---$ & NetworkO & .155 & .027 & 5.798 & ${ }^{* * *}$ \\
NetworkB $<---$ & NetworkM & .063 & .019 & 3.260 & .001 \\
SocialC $<---$ & NetworkB & .145 & .039 & 3.708 & ${ }^{* * *}$ \\
TacitK $<---$ & NetworkB & .90 & .042 & 21.508 & ${ }^{* * *}$ \\
VentureP $<---$ & NetworkB & .330 & .171 & 1.923 & .035 \\
VentureP $<---$ & TacitK & .169 & .034 & 4.986 & .024 \\
VentureP $<---$ & SocialC & .356 & .061 & 5.884 & ${ }^{* * *}$ \\
VentureP $<---$ & Gender & -.047 & .045 & -1.041 & .298 \\
VentureP $<---$ & Education & .015 & .070 & .210 & .834 \\
\hline
\end{tabular}

Source: Author's compilation

Table 4.5 Mediation Effects

\begin{tabular}{|l|llc|}
\hline & NetworkB & TacitK & SocialCap \\
\hline TacitK & .331 & .000 & .000 \\
SocialCap & .50 & .000 & .000 \\
VentureP & .199 & .391 & .280 \\
\hline
\end{tabular}

Table 4.6 Mediation Analysis

\begin{tabular}{|c|c|c|c|c|c|c|}
\hline Effects & Path & $\begin{array}{c}\text { Path } \\
\text { estimates }\end{array}$ & $\begin{array}{c}\text { Indirect } \\
\text { effect }\end{array}$ & $\begin{array}{l}\text { Total } \\
\text { effects }\end{array}$ & VAF & Mediation \\
\hline $\begin{array}{l}\text { Direct effects in the } \\
\text { two models }\end{array}$ & VentureP <---NetworkB & 0.199 & $\begin{array}{c}\text { Not } \\
\text { applicable }\end{array}$ & & & \\
\hline \multirow{4}{*}{$\begin{array}{l}\text { Indirect effects of } \\
\text { mediators }\end{array}$} & SocialCap <---NetworkB & 0.50 & \multirow{2}{*}{0.140} & \multirow{2}{*}{0.339} & \multirow{2}{*}{$41.30 \%$} & \multirow{2}{*}{ Partial } \\
\hline & VentureP <---SocialC & 0.280 & & & & \\
\hline & TacitK <---NetworkB & 0.331 & \multirow{2}{*}{0.129} & \multirow{2}{*}{0.328} & \multirow{2}{*}{$39.33 \%$} & \multirow{2}{*}{ Partial } \\
\hline & VentureP <---TacitK & 0.391 & & & & \\
\hline
\end{tabular}

Source: Authors compilation 
Table 4.7 Indirect Effects - Upper and Lower Bounds

\begin{tabular}{|c|ccc|}
\hline Upper Bounds & NetworkB & TacitK & SocialCap \\
\hline TacitK & .000 & .000 & .000 \\
SocialCap & .000 & .000 & .000 \\
& & & \\
VentureP & .042 & .000 & .000 \\
& & & \\
Lower Bounds & & & \\
\cline { 1 - 1 } TacitK & 0.000 & 0.000 & 0.000 \\
SocialCap & 0.000 & 0.000 & 0.000 \\
VentureP & 0.201 & 0.000 & 0.000 \\
& & & \\
\hline
\end{tabular}

Source: Authors compilation

The extent of mediation was determined based on Hair Jr et al. (2014) suggestion of the application of variance accounted for $(\mathrm{VAF})^{3}$ and that VAF helps to determine whether a variable fully or partial mediates or do not mediates at all. They further stated that no mediation is reported when the VAF value is less than 20, partial mediation is reported when the VAF value is between 20 and 80 percent whilst VAF value higher than 80 percent means full mediation. Based on the VAF results, tacit knowledge and social capital partially mediated the association between network behaviour and venture performance (VAF of social capital $=41.3 \%$, VAF of tacit knowledge acquisition $=$ $39.3 \%)$.

\section{DISCUSSION AND IMPLICATION}

Entrepreneurs require resources in different forms, knowledge, information and markets in the

\footnotetext{
${ }^{3} \mathrm{VAF}=$ indirect effect/total effect $* 100$

Total effect $=$ indirect effect + direct effect
}

entrepreneurial process. These resources may come from the entrepreneur's personal savings, skills, information and knowledge. Entrepreneurial resources can also be mobilised from the available formal systems. However, many entrepreneurs are unable to access the needed resources from these mechanisms. Therefore, there is the need for entrepreneurs to develop certain mechanisms which help them to exploit the needed resources, market, information and technology.

The study explored entrepreneurs' network behaviour as a mechanism through which entrepreneurs can influence venture performance. The results of the study revealed that entrepreneurs who engage in or exhibit the attitude of developing social networks are able to positively influence venture performance. Entrepreneurs network behaviour had a positive and significant effect on venture performance. This finding is in tandem with previous researchers' empirical studies acknowledging the relevance of 
social networks in the entrepreneurial process including the growth and performance of entrepreneurial startups. For instance, (Javalgi, Hall, \& Cavusgil, 2014) revealed that entrepreneur maintaining quality social network helps to increase their knowledge and expertise in their line of business as well as exploit other related opportunities and enhance their ability to learn from others.

Again, this finding in line with Hom and Xiao (2011) view that entrepreneurial network facilitates the discovery of related activities such as the supply chain since that go a long way to positively enhance performance. The finding further buttressed (Yeung, 2002) that when entrepreneurs engage in social network, they turn to be more creative, experienced and successful in risk management. Similarly, since superior performance is key to success, the finding support (De Bruin et al., 2007) that networking behavior leads to a higher probability of success.

From the findings, it is undoubtedly clear that when entrepreneurs exhibit network behaviour they will be in a better position to achieve superior performance. Entrepreneurs whether nascent or existing need to develop the attitude towards engaging in network activities since that serve as a conduit for them to realize the purpose of becoming an entrepreneur and positively growing their businesses. Entrepreneurs need to be rooted in network behaviour as the findings of the study highlighted the direct and significant influence of social networks on startups performance hence achieving sustained business performance in this contemporary, dynamic, turbulent business environment will depend on entrepreneurs who create network relationships.

The findings of the study also revealed that entrepreneur's network behaviour leads to social capital. Network behaviour had a significant effect on social capital. The finding implies that when entrepreneurs build, maintain and configure their social networks will lead to social capital. Social capital was also found to enhance the relationship between network behaviour and venture performance. These findings are line with researchers such as Marsden (2017) and Wu and Chiu (2018) view that social capital boost attitudes of entrepreneurs and consequently helps in the establishment of a new business startup.

The finding meticulously buttresses Hoang and Antoncic (2003) assertion that social capital allows entrepreneurs make good use of the value of other resources thereby enhances the presence of a positive association between social capital and of a new venture financial success. Therefore, social network serves as a means by which entrepreneurs can achieve their goals. The findings similarly support Van Laere (2003) expression of the linkage of the concept of social capital with social network pointing out that an individual position in a social network might serve as a mechanism through which the individual can achieve competitive advantage that could result in superior performance.

In the entrepreneurial process, skills, knowledge and expertise play important role as far as organizing entrepreneurial startups are concern. Therefore, entrepreneurs need to acquire such knowledge. Whilst entrepreneurs can easily access codified knowledge, it is very difficult for the acquisition of non-codified aspect of knowledge (tacit knowledge). For entrepreneurs to acquire such knowledge, it is important for them to engage in network activities since social ties represents a means through which tacit knowledge can be acquired.

The findings reveal that network behavior helps entrepreneurs to acquire tacit knowledge. Thus, network behaviour had a direct and significant effect on tacit knowledge acquisition. The study finding 
indicates that tacit knowledge also influences venture performance whilst it better facilitates the relationship between entrepreneurs who engaged in social network activities and business performance. Accordingly, the confirmation of the mediation role of tacit knowledge acquisition in the findings is a revelation of the importance of the knowledge acquisition mechanism in the entrepreneurial process. The study findings support previous researchers who established that network facilitates the acquisition of tacit knowledge which enhances competitive advantage (Nonaka et al., 2014). The findings strengthen Braunerhjelm (2011) and Giju et al. (2010) emphasis that entrepreneurs need to fully rely on their social network to tap and share experience and knowledge from other related industries and ventures that are performing well so as to prevent failure.

The findings are in accordance with Bartol and Srivastava (2002) assertion that tacit knowledge helps entrepreneurs to be successful. The findings of the study suggest that entrepreneurs through their network behaviours acquire tacit knowledge which propels startup performance. Therefore, entrepreneurs who are embedded in social ties wield the ability to overcome the challenge of resource limitations and undertake innovative strategies that propels competitive advantage hence leverage on firm performance.

\section{IMPLICATION}

The study was carried out in the context of entrepreneur behaviours mechanisms and startup business performance. The study findings present some implications for entrepreneurship research, researchers, practitioners, policy makers, managers, academics and government. These implications would help to shed light on contributing to entrepreneurship and thereby advances the means of improving the entrepreneurial process and exceedingly contribute to knowledge.

The revelation of networking behaviour as a mechanism for entrepreneurs to influence their business performance implies that managers, practitioners and businesses would have alternative means of accessing and mobilising resources, opportunities, information, and technology to help them sustain their businesses through superior performance. This study presents to these agents in the entrepreneurial process the opportunity to better understand and develop social ties within and outside the business environment. Since resources constraints especially accessing the needed entrepreneurial resources from formal institutions and systems are difficulty if not impossible, entrepreneurs should pay attention to building, maintaining and configuring their social relationships as that serve as a platform for accessing and marshalling entrepreneurial resources, opportunities and information.

Also, the understanding of the entrepreneurial behavior is appreciated when researchers try to examine that part of the behavior which the entrepreneur can control. Departing from the psychological perspective which mainly focus on stable features of the entrepreneur to include the behaviour mechanisms make the study central to better understand the entrepreneurial process.

\section{REFERENCES}

[1]. AMEH, A. A. \& UDU, A. A. 2016. Social networks and entrepreneurship orientation among students in nigerian universities: a study of social network size and risk disposition. Business and Management Research, 5, 1-11.

[2]. BARTOL, K. M. \& SRIVASTAVA, A. 2002. Encouraging knowledge sharing: The role of 
organizational reward systems. Journal of Leadership \& Organizational Studies, 9, 64-76.

[3]. BAUMOL, W. J. 2007. Entrepreneurship and innovation: The (Micro) theory of price and profit. File: Entpricetheory-w-apr-4-2007.

[4]. BRAUNERHJELM, P. 2011. Entrepreneurship, innovation and economic growth: interdependencies, irregularities and regularities. Handbook of Research on Innovation and Entrepreneurship. Elgar: Cheltenham, 161-213.

[5]. CASCIARO, T., GINO, F. \& KOUCHAKI, M. 2016. Learn to love networking. Harvard Business Review, 94, 104-107.

[6]. DE BRUIN, A., BRUSH, C. G. \& WELTER, F. 2007. Advancing a framework for coherent research on women's entrepreneurship. Entrepreneurship theory and practice, 31, 323339.

[7]. DE CAROLIS, D. M. L., BARRIE E, EDDLESTON, KIMBERLY A 2009. Why networks enhance the progress of new venture creation: The influence of social capital and cognition. Entrepreneurship Theory and Practice, 33, 527-545.

[8]. DUFAYS, F. \& HUYBRECHTS, B. 2014. Connecting the dots for social value: A review on social networks and social entrepreneurship. Journal of Social Entrepreneurship, 5, 214-237.

[9]. EDDLESTON, K. A., LADGE, J. J., MITTENESS, C. \& BALACHANDRA, L. 2016. Do you see what I see? Signaling effects of gender and firm characteristics on financing entrepreneurial ventures. Entrepreneurship Theory and Practice $40,489-514$

[10]. GARTNER, W. B. 1988. "Who is an entrepreneur?" is the wrong question. American journal of small business, 12, 11-32.

[11]. GEENEN, N. Y., URBIG, D., MUEHLFELD, K., VAN WITTELOOSTUIJN, A. \& GARGALIANOU, V. 2016. BIS and BAS:
Biobehaviorally rooted drivers of entrepreneurial intent. Personality Individual Differences. 95, 204-213.

[12]. GIJU, G. C., BADEA, L., RUIZ, V. R. L. \& PEÑA, D. N. 2010. Knowledge Managementthe Key Resource in the Knowledge Economy. Theoretical Applied Economics, 17.

[13]. GREBEL, T. 2005. Entrepreneurship: A new perspective, Routledge.

[14]. HAFEEZ, K. \& ABDELMEGUID, H. 2003. Dynamics of Human Resource and Knowledge Management. The Journal of the Operational Research Society, 54, 153-164.

[15]. HAIR, J. F., RINGLE, C. M. \& SARSTEDT, M. 2013. Partial least squares structural equation modeling: Rigorous applications, better results and higher acceptance.

[16]. HAIR JR, J. F., SARSTEDT, M., HOPKINS, L. \& KUPPELWIESER, V. G. J. E. B. R. 2014. Partial least squares structural equation modeling (PLSSEM).

[17]. HOANG, H. \& ANTONCIC, B. 2003. Networkbased research in entrepreneurship: A critical review. journal of Business Venturing, 18, 165187.

[18]. HOM, P. W. \& XIAO, Z. 2011. Embedding social networks: How guanxi ties reinforce Chinese employees' retention. Organizational Behavior and Human Decision Processes, 116, 188-202.

[19]. HOOGENDOORN, B., VAN DER ZWAN, P. \& THURIK, R. J. J. O. B. E. 2019. Sustainable entrepreneurship: The role of perceived barriers and risk. 157, 1133-1154.

[20]. IBARRA, H., KILDUFF, M. \& TSAI, W. J. O. S. 2005. Zooming in and out: Connecting individuals and collectivities at the frontiers of organizational network research. 16, 359-371.

[21]. JAVALGI, R. G., HALL, K. D. \& CAVUSGIL, S. T. 2014. Corporate entrepreneurship, customeroriented selling, absorptive capacity, and 
international sales performance in the international B2B setting: Conceptual framework and research propositions. International Business Review, 23, 1193-1202.

[22]. KLOEPFER, K. \& CASTROGIOVANNI, G. J. 2018. Entrepreneurship: venture creation subprocesses, subdomains, and interfaces. International Entrepreneurship Management Journal, 14, 681-696.

[23]. KOGAN, L., PAPANIKOLAOU, D., SERU, A. \& STOFFMAN, N. J. T. Q. J. O. E. 2017. Technological innovation, resource allocation, and growth. 132, 665-712.

[24]. KYNDT, E. \& BAERT, H. J. J. O. V. B. 2015. Entrepreneurial competencies: Assessment and predictive value for entrepreneurship. 90, 1325.

[25]. LANIVICH, S. E. \& PRACTICE 2015. The RICH entrepreneur: Using conservation of resources theory in contexts of uncertainty. Entrepreneurship Theory, 39, 863-894.

[26]. LOEBBECKE, C., VAN FENEMA, P. C. \& POWELL, P. J. T. J. O. S. I. S. 2016. Managing inter-organizational knowledge sharing. 25, 414.

[27]. MARSDEN, P. V. 2017. Interpersonal ties, social capital, and employer staffing practices. Social capital. Routledge.

[28]. MAURER, I. \& EBERS, M. 2006. Dynamics of social capital and their performance implications: Lessons from biotechnology startups. Administrative Science Quarterly, 51, 262292.

[29]. MEMON, N. 2016. Entrepreneurship in the eyes of network science. Procedia Computer Science, 91, 935-943.

[30]. MORRISON, A. 2006. A contextualisation of entrepreneurship. International Journal of Entrepreneurial Behavior \& Research.
[31]. NAHAPIET, J. \& GHOSHAL, S. J. A. O. M. R. 1998. Social capital, intellectual capital, and the organizational advantage. 23, 242-266.

[32]. NJARAMBA, J., CHIGEZA, P. \& WHITEHOUSE, H. 2015. financial literacy: the case of migrant African-Australian women entrepreneurs in the cairns region. Entrepreneurship Sustainability Issues, 3, 198208.

[33]. NONAKA, I., KODAMA, M., HIROSE, A. \& KOHLBACHER, F. J. E. M. J. 2014. Dynamic fractal organizations for promoting knowledgebased transformation-A new paradigm for organizational theory. 32, 137-146.

[34]. PIERCY, N. F., KALEKA, A. \& KATSIKEAS, C. S. 1998. Sources of competitive advantage in high performing exporting companies. Journal of World Business, 33, 378-393.

[35]. POLANYI, M. T. 1966. 1966 The tacit dimension. London: Routledge \& Kegan Paul.

[36]. PREACHER, K. J. \& HAYES, A. F. J. B. R. M. 2008. Asymptotic and resampling strategies for assessing and comparing indirect effects in multiple mediator models. 40, 879-891.

[37]. RYAN, S. D., ZHANG, X., PRYBUTOK, V. R. \& SHARP, J. H. 2012. Leadership and knowledge management in an e-government environment. Administrative sciences, 2, 63-81.

[38]. SEIDLER-DE ALWIS, R. \& HARTMANN, E. 2008. The use of tacit knowledge within innovative companies: knowledge management in innovative enterprises. Journal of knowledge management.

[39]. SEMRAU, T. \& SIGMUND, S. 2012. Networking ability and the financial performance of new ventures: A mediation analysis among younger and more mature firms. Strategic Entrepreneurship Journal, 6, 335-354.

[40]. SHU, R., REN, S. \& ZHENG, Y. Build Network before use it: Entrepreneur Network Capability and Opportunity Discovery. Academy of 
Management Proceedings, 2017. Academy of Management Briarcliff Manor, NY 10510, 12928.

[41]. SU, C., YANG, Z., ZHUANG, G., ZHOU, N. \& DOU, W. 2009. Interpersonal influence as an alternative channel communication behavior in emerging markets: The case of China. Journal of International Business Studies, 40, 668-689.

[42]. SU, J., ZHAI, Q. \& KARLSSON, T. 2017. Beyond red tape and fools: Institutional theory in entrepreneurship research, 1992-2014. Entrepreneurship Theory and Practice, 41, 505531.

[43]. TASKOV, N., BOSKOV, T., METODIJESKI, D. \& FILIPOSKI, O. 2011. Enterpreneurship in tourism industry lead to business benefits.

[44]. THOMPSON, B. 2003. Guidelines for authors reporting score reliability estimates. Score reliability: Contemporary thinking on reliability issues, 91-102.

[45]. VAN LAERE, K. J. J. O. W. L. 2003. Social networks as a source of competitive advantage for the firm.

[46]. WEI, L.-Q. \& LING, Y. J. J. O. B. R. 2015. CEO characteristics and corporate entrepreneurship in transition economies: Evidence from China. 68, 1157-1165.

[47]. WIKLUND, J., NIKOLAEV, B., SHIR, N., FOO, M.-D. \& BRADLEY, S. 2019. Entrepreneurship and well-being: Past, present, and future. Elsevier.

[48]. WONG, P. K., HO, Y. P. \& AUTIO, E. 2005. Entrepreneurship, innovation and economic growth: Evidence from GEM data. Small business economics, 24, 335-350.

[49]. WU, L. \& CHIU, M.-L. J. I. J. O. I. M. 2018. Examining supply chain collaboration with determinants and performance impact: Social capital, justice, and technology use perspectives. 39, 5-19.
[50]. XIE, Y., DU, Y.-F., BOADU, F. \& SHI, X.-Y. J. S. 2018. Executives' Assessments of Evolutionary and Leapfrog Modes: An Ambidexterity Explanation Logic. 10, 2893.

[51]. YEUNG, H. W.-C. 2002. Entrepreneurship in international business: An institutional perspective. Asia Pacific Journal of Management, 19, 29-61.

[52]. ZHENG, N., WEI, Y., ZHANG, Y. \& YANG, J. J. I. B. R. 2016. In search of strategic assets through cross-border merger and acquisitions: Evidence from Chinese multinational enterprises in developed economies. 25, 177186.

\section{Cite This Article :}

Isaac Gumah Akolgo, Cai Li, Peter Yao Lartey, Kankam William Adomako, " Entrepreneur Network Behavior as the Gamechanger for Venture Performance : the Mediation Effect of Social Capital and Tacit Knowledge", International Journal of Scientific Research in Science and Technology(IJSRST), Print ISSN : 2395-6011, Online ISSN : 2395-602X, Volume 7, Issue 2, pp.482-501, March-April-2020. Available at doi : https://doi.org/10.32628/IJSRST207287 Journal URL : http://ijsrst.com/IJSRST207287 